Eur. J. Clin. Chem. Clin. Biochem.

Vol. 29, 1991, pp. 313-315

(C) 1991 Walter de Gruyter \& Co.

Berlin - New York

\title{
Deficiency of Porphobilinogen Synthase Associated with Acute Crisis Diagnosis of the First Two Cases in Chile by Laboratory Methods
}

\author{
By C. Wolff, F. Piderit and R. Armas-Merino \\ Department of Medicine, Universidad de Chile, Hospital San Juan de Dios, Santiago, Chile
}

(Received September 3, 1990/January 3, 1991)

Summary: Erythrocyte porphobilinogen synthase deficiency was confirmed by the determination of its activity in blood and also by the high levels of both porphyrins and 5-aminolaevulinic acid in the urine of two siblings. They presented with a picture of porphyric attack characterized by abdominal colic pain, high blood pressure, tachycardia and severe constipation. The profile of both porphyrins and their precursors in urine and blood resembled lead poisoning. However, this was ruled out because both patients had normal-blood levels of lead. Furthermore, porphobilinogen synthase activity did not normalize when it was determined in the presence of dithiothreitol or dithiothreitol plus zinc chloride. No other causes to account for a deficiency in porphobilinogen synthase activity were identified.

The simultaneous occurrence of similar clinical and biochemical symptoms suggests that the same triggering factor was present. Because the activity of porphobilinogen synthase was less than $4 \%$ of normal values, it is possible that these patients were homozygotes with respect to this defect, which could explain the presence of clinical symptoms. We propose that this metabolic defect is not uncommon and it should be kept in mind when diagnosing of porphyrias or heavy metal intoxications.

\section{Introduction}

Porphobilinogen synthase (EC 4.2.1.24; synonym 5aminolaevulinic acid dehydr(at)ase) ${ }^{1}$ ) activity below $50 \%$ can be found in up to $2 \%$ of the general population (1). The identification of families with asymptomatic members whose porphobilinogen synthase activity was 25 to $50 \%$ below the reference values has given some clues regarding a genetic transmission of this defect $(2,3)$.

In 1979, Doss (4) described two young men who presented with severe inhibition of erythrocyte porphobilinogen synthase activity associated to acute porphyric crisis since adolescence. The pattern of excretion of both porphyrins and their precursors was similar to a picture of lead poisoning. Since then, two

\footnotetext{
1) Enzyme:

Porphobilinogen synthase $=5$-aminolaevulinic acid dehydratase (EC 4.2.1.24)
}

other cases have been described: a child with severe neurologic symptoms associated to haemolytic anaemia since birth (1) and a man who at 63 presented for the first time a typical acute porphyric crisis (5).

The activity of porphobilinogen synthase is under the control of an autosomic gene with 2 alleles (6) located in chromosome 9 (1). Biochemical $(7,8)$ and immunological $(1,9)$ studies to characterize this enzyme indicate that a mutation of the structural gene could be responsible for its inhibition. The defective gene is inherited as an autosomal dominant trait $(2,3)$, whereas the more common kinds of porphyria are inherited recessively. Acute crises occur in people who are homozygous for the defect (7). In these cases, the level of porphobilinogen synthase approaches zero. Heterozygous subjects have enzyme levels in the midrange and have no symptoms.

Several elements and chemical compounds can inhibit a specific enzyme of haem biosynthesis, thereby caus- 
ing a true picture of porphyria, namely an acquired form of porphyria. This takes place, for instance, in heavy metal intoxications, especially with lead (3). Other heavy metals like aluminium, mercury and cadmium do not produce inhibition of porphobilinogen synthase in concentrations that are toxic in vivo (5). High levels of lead displace zinc from the porphobilinogen synthase, generating an intense inhibition of enzymatic activity, with an accumulation of the substrate 5-aminolaevulinic acid, which then increases in the urine. Therefore, to confirm the diagnosis of hereditary porphobilinogen synthase deficiency, it is necessary to rule out lead intoxication.

This work describes the confirmation, by laboratory means, of porphobilinogen synthase deficiency in two brothers from a rural zone who presented with clinical manifestations compatible with a porphyric acute crisis.

\section{Patients Description}

Two brothers (aged 26 and 28 years), farmers from Lumaco, a village located 750 kilometers south of Santiago, presented with similar symptoms within 10 days of each other: arterial hypertension, tachycardia, severe constipation and intense colic pain in the lower abdominal region, which did not respond to antispasmodic drugs. They had no fever or anaemia, and the urine sediment was normal. They were not alcoholics or carriers of any chronic diseases. Intestinal obstruction, salmonellosis, and other infectious diseases were ruled out. There was no clinical evidence of tyrosinaemia, diabetes or renal insufficiency. They were neither taking any kind of drugs nor were they fasting. Neither patient showed any cutaneous lesions during the clinical course of their disease.
The casual observation that the urine turned dark when it was exposed to light, led us to consider the possibility of an acute crisis of porphyria.

\section{Methods}

Levels of porphobilinogen (10), 5-aminolaevulinic acid (11) coproporphyrin and uroporphyrin (12) were determined in urine samples. Coproporphyrin and protoporphyrin (12) were determined in faecal samples. Blood levels of erythrocyte protoporphyrin (13) and the enzymatic activity of porphobilinogen synthase (5) were evaluated in the presence of dithiothreitol, 10 $\mathrm{mmol} / \mathrm{l}$, to eliminate any possible action of lead on porphobilinogen synthase activity (14). Enzyme activity was evaluated with and without zinc chloride $0.1 \mathrm{mmol} / \mathrm{l}$. Serum levels of lead were measured by electrothermal atomic absorption spectroscopy (15).

\section{Results}

Determinations of the level of both porphyrins and their precursors in urine, faeces and blood (tab. 1, 1st evaluations) showed a typical pattern of lead intoxication. Nevertheless, a thorough search for a possible lead contact proved negative.

In a second laboratory check-up a few months later, the patients were asymptomatic (tab. 1, 2nd evaluation) showing a blood lead level within permissible limits and erythrocyte porphobilinogen synthase activity significantly decreased when compared with normal healthy control subjects. No normalization of activity was observed when the enzyme activity was determined in the presence of dithiothreitol or dithiothreitol plus zinc ions.

Tab. 1. Laboratory results in both patients (A and B) on two occasions, 1st evaluation during acute crisis and 2nd evaluation while asymptomatic.

\begin{tabular}{|c|c|c|c|c|c|c|}
\hline & & \multirow[t]{2}{*}{$\begin{array}{l}\text { Reference } \\
\text { values }\end{array}$} & \multicolumn{2}{|c|}{$\begin{array}{l}\text { 1st evaluation } \\
\text { Patient } \\
\end{array}$} & \multicolumn{2}{|c|}{$\begin{array}{l}\text { 2nd evaluation } \\
\text { Patient }\end{array}$} \\
\hline & & & $\bar{A}$ & B & $\mathrm{A}$ & $\mathrm{B}$ \\
\hline \multicolumn{7}{|l|}{ Urine sample } \\
\hline $\begin{array}{l}\text { 5-Aminolaevulinate } \\
\text { Porphobilinogen } \\
\text { Coproporphyrin } \\
\text { Uroporphyrin }\end{array}$ & $\begin{array}{l}\mu \mathrm{mol} / \mathrm{day} \\
\mu \mathrm{mol} / \mathrm{day} \\
\mathrm{nmol} / \mathrm{day} \\
\mathrm{nmol} / \mathrm{day}\end{array}$ & $\begin{array}{l}12.5-52.3 \\
\text { Up to } 5.3 \\
\text { Up to } 228 \\
\text { Up to } 21\end{array}$ & $\begin{array}{l}397.1 \\
15.0 \\
4101 \\
\text { ND }\end{array}$ & $\begin{array}{l}370.1 \\
17.2 \\
2660 \\
\text { ND }\end{array}$ & $\begin{array}{c}42.0 \\
5.7 \\
398 \\
42\end{array}$ & $\begin{array}{r}61.5 \\
6.2 \\
184 \\
46\end{array}$ \\
\hline \multicolumn{7}{|l|}{ Stool sample } \\
\hline $\begin{array}{l}\text { Coproporphyrin } \\
\text { Protoporphyrin }\end{array}$ & $\begin{array}{l}\mathrm{nmol} / \mathrm{g} \text { dry weight } \\
\mathrm{nmol} / \mathrm{g} \text { dry weight }\end{array}$ & $\begin{array}{l}\text { Up to } 26 \\
\text { Up to } 48\end{array}$ & $\begin{array}{r}7.0 \\
15.0\end{array}$ & $\begin{array}{r}6.9 \\
14.4\end{array}$ & $\begin{array}{l}0.3 \\
1.6\end{array}$ & $\begin{array}{l}2.0 \\
1.1\end{array}$ \\
\hline \multicolumn{7}{|l|}{ Blood sainple } \\
\hline $\begin{array}{l}\text { Protoporphyrins } \\
\text { Porphobilinogen synthase* } \\
\text { Porphobilinogen synthase** } \\
\text { Lead } \\
\text { Red blood cells }\end{array}$ & $\begin{array}{l}\mu \mathrm{mol} / 1 \text { erythrocytes } \\
U / 1 \text { erythrocytes } \\
U / 1 \text { erythrocytes } \\
\text { mmol/l } \\
10^{12} / 1\end{array}$ & $\begin{array}{l}\text { Up to } 1.0 \\
18-50 \\
18-50 \\
\text { Up to } 1.6 \\
4.5-5.5\end{array}$ & $\begin{array}{l}4.0 \\
- \\
- \\
-\end{array}$ & $\begin{array}{l}4.1 \\
- \\
- \\
-\end{array}$ & $\begin{array}{l}0.52 \\
1.50 \\
2.50 \\
0.90 \\
5.1\end{array}$ & $\begin{array}{l}0.67 \\
1.70 \\
3.60 \\
1.01 \\
5.0\end{array}$ \\
\hline
\end{tabular}




\section{Discussion}

Acute hepatic porphyric syndrome linked to a porphobilinogen synthase deficiency was first reported by Doss et al. (4) in two young patients who presented with an activity of this enzyme below $1 \%$ of the value of normal control subjects. Since then, two other cases have been described in the literature.

Normally, porphobilinogen synthase activity is in considerable excess and for this reason it is not a rate limiting step. To influcnce haem biosynthesis, the inhibition must be more than $90 \%$. This degree of inhibition is manifested clinically (8), and it is found only in patients who are homozygous for the defect (16); the two brothers in the present study are homozygotes. In heterozygous patients, the clinical and biochemical evidence is slight or absent.

The low incidence of homozygous patients in spitc of the fact that heterozygotes are not that rare could reflect the fact that this condition is incompatible with life and could be a cause of spontaneous abortion (1). On the other hand, this disease is considered a rarity by clinicians and is not thought of as a possible diagnosis even when a patient has typical symptomatology. It should be kept in mind when other types of porphyria or heavy metal intoxications are diagnosed.

\section{References}

1. Thunell, S. (1987) Aminolaevulinate dehydratase porphyria in infancy. A clinical and biochemical study. J. Clin. Chem. Clin. Biochem. 25, 5-14.

2. Bird, T. D., Hameernyik, P., Nutter, J. Y. \& Labbé, R. F. (1979) Inherited deficiency of delta-aminolevulinic acid dehydratase. Am. J. Hum. Genet. 31, 662-668.

3. Doss, M., Laubenthal, F. \& Stoeppler, M. (1984) Lcad poisoning in inherited $\delta$-aminolevulinic acid dehydratase deficiency. Int. Arch. Occup. Environ. Health 54, 55-63.

4. Doss, M., Tiepermann, R., Schneider, J. \& Schmid, H. (1979) New type of hepatic porphyria with porphobilinogen synthase defect and intermittent acute clinical manifestation. Klin. Wochenschr. 57, 1123-1127.

5. Hassoun, A., Verstraeten, L., Mercellis, R. \& Martin, J. J. (1989) Biochemical diagnosis of an hereditary aminolevulinate dehydratase deficiency in a 63-years old man. J. Clin. Chem. Clin. Biochem. 27, 781-786.

6. Verneuil, H., Doss, M., Brusco, N., Beaumont, C. \& Nordmann, Y. (1985) Hereditary hepatic porphyria with delta aminolevulinate dehydrase deficiency: immunologic characterization of the non-catalytic enzyme. Hum. Genet. 69 , $174-177$.

7. Brand, A. \& Doss, M. (1981) Hereditary porphobilinogen synthase deficiency in human associated with acute hepatic porphyria. Hum. Genet. 58, 194-197.

8. Doss, M. (1986) Enzymatic deficiencies in acute hepatic porphyrias: Porphobilinogen synthase deficiency. Semin. Dermatol. 5, 161-168.

9. Fujita, H., Sissa, S., Lundgren, J., Holmberg, L., Thunell, S. \& Kappas, A. (1987) Enzymatic defect in a child with hereditary hepatic porphyria due to homozygous $\delta$-ami-
This paper describes two new patients who are brothers and who within a period of ten days presented with an acute crisis similar to those observed in other types of porphyria. The patients had arterial hypertension, tachycardia, constipation, abdominal pain, and a diagnostic sign of porphyria: blackening of the urine when exposed to sunlight.

The pattern of urine excretion and blood levels of both porphyrins and their precursors were closely similar to those found in lead poisoning. Although the factor that triggered the crisis in our two patients could not be identified, it is clear that lead was not involved, because blood levels were normal, and there was no normalization of porphobilinogen synthase activity when dithiothreitol was added to the enzyme assay medium. Moreover, the activity of this enzyme did not reach normal levels when zinc ions were added to the final assay (14). As in our cases, a triggering factor could not be identified in the three adult patients reported in the literature.

The fact that these two patients are brothers and have similar life styles, and they simultaneously presented with an acute crisis, strongly suggests that a genetic defect was expressed by a common triggering factor.

In both patients, clinical manifestation subsided spontaneously without specific treatment.

nolcvulinic acid dchydratasc deficiency: Immunochemical studies. Pediatrics $80,880-885$.

10. Mauzcrall, D. \& Granick, S. (1956) The occurrence and determination of $\delta$-aminolevulinic acid and porphobilinogen in urine. J. Biol. Chem. 219, 435-446.

11. Wolrf, C. (1974) Método simplificado para la detcrminación de ácido aminolevulínico como indicador de intoxicación plúmbica. Rev. Med. Chile 102, 227-230.

12. Schwartz, S., Berg, M. H., Bossenmaier, I. \& Dinsmore, H. (1960) Determination of porphyrin in biological materials. In: Methods in Biochemical Analy'sis (Glick, D., ed.) Vol. VIII, pp. 221 - 293 Interscience Publishers New York and London.

13. Heller, S. R., Labbé, F. R. \& Nutter, J. (1971) A simplified assay for porphyrins in whole blood. Clin. Chem. 17, 525528.

14. Sakai. T., Yanagihara, S. \& Ushio, K. (1980) Restoration of lead inhibited 5-aminolevulinate dehydrogenase activity in whole by heat, zinc ion, and (or) dithiothreitol. Clin. Chem. 26. 625-628.

15. Hessel, D. W. (1968) A simple and rapid quantitative determination of lead in blood. Atomic ABS Newsletter 7. $55-58$.

16. Labbé, R. F. \& Bird. T. J. (1985) More on identifying inherited deficiency of porphobilinogen synthase. Clin. Chem. 31, 162.

Dr. Carlos Wolff

Universidad de Chile

Hospital San Juan de Dios

Departmonto de Medicini

Casilla 33052

Santiago, Chile 
